\title{
D-4 GENERAL TECTONIC FRAMEWORK OF THE EASTERN MEDITERRANEAN
}

J.M. WOODSIDE

Amsterdam Free University, Centre for Marine Earth Sciences, De Boelelaan 1085, 1081 HV Amsterdam, The Netherlands

\section{Introduction}

Our understanding of the tectonic framework of the eastern Mediterranean has greatly improved in the past ten years or so. New research has benefited from deep sea drilling by the Ocean Drilling Program (ODP), the extensive use of new techniques such as multibeam swath mapping, unexpected results from investigations of mud volcanoes and fluid seeps, and exploration of areas of potential resources like the Nile offshore. Furthermore, continued mapping on land - both geologic and geodetic (e.g. with GPS) - has provided new constraints for the evolution of the region. Nevertheless, the region remains poorly known because of difficulties not only in resolving many basic problems such as the age, nature, and configuration of the ocean basin but also in seeing below often thick Messinian salt or so-called cobblestone relief of the Mediterranean Ridge. This paper is a general overview of the tectonic framework of the eastern Mediterranean from the point of view of one researcher.

\section{Basic neotectonic elements}

Early views on the plate tectonic situation (McKenzie, 1972) have been largely confirmed by direct geodetic measurements of the surrounding landmass (Le Pichon et al., 1995; McClusky et al., 2000). Distribution of observation stations and the inability yet to survey submarine parts of the region means that details must be provided by seismicity and marine geophysical surveys.

Since mid-Cretaceous there has been convergence between the Eurasian and African plates. In broad terms, progressive plate collision occurs from east to west: it is essentially complete between both major plates in southeastern Turkey, underway along the Cyprus Arc, and just about to start along the Hellenic Arc. Since Late Miocene two microplates (the Anatolian and Aegean plates) have accommodated continued convergence of the African and Eurasian plates by moving laterally (westward tectonic escape) towards remaining regions of oceanic lithosphere (McKenzie, 1972; McClusky et al., 2000). Within the zone of collision, smaller units accommodate movement locally (see below). To the south of the plate boundary lies the old original ocean basin dating probably from early Mesozoic (possibly originating from late Permian rifting along the north African margin) - the Ionian and Levantine Basins (fig. 1); but to the north, smaller basins record various stages in closure of the eastern Mediterranean basin.

The plate boundary follows the Cyprus and Hellenic Arcs with a southward offset which is smaller south of Cyprus than south of Crete where thinned continental basement continues beneath the Hellenic Trench to the Mediterranean Ridge. Similar thinned continental basement extends beneath the Anaximander Mountains from Turkey (fig. 2). It is not clear how the plate 
boundary crosses through the region of the Anaximander Mountains. It could be speculated, however, that the region southeast of the Burdur fault zone in Turkey, west of Antalya, and including the Anaximander Mountains in the south, is an accommodation zone for relative plate interaction. The Anaximander Mountains form at least three independently moving, faultbounded blocks. Subduction continues along the west and southwest arms of the Hellenic Arc but probably since late Miocene there is transpression along the Pliny-Strabo Trench system in the east.

North of the plate boundary lie basins of various ages. Several of these, like the Adana and Cilicia basins to the north of Cyprus (fig. 1) originated in late Oligocene to early Miocene (Robertson, 1998). Later developments caused their continuing tectonic evolution to diverge (e.g. uplift of the basins north of the suture zone in southeast Turkey but continuing subsidence in the Cilicia Basin). Other basins like the Rhodes and Finike Basin west and north of the Anaximander Mountains (fig. 1), respectively, are post Miocene (Woodside et al., 2000a). The Antalya Basin probably dates from early Miocene, similar to the Cretan Basin, but shows evidence of increased subsidence and northward tilting in post Miocene time, in contrast to uplift in Cyprus and the adjacent Taurides. These basins are in general underlain by nappes emplaced from the north (Sage and Letouzey, 1990).

Collision of Eratosthenes Seamount with Cyprus in Pliocene time caused general uplift in Cyprus into the Pleistocene and subsidence of Eratosthenes with breakup and collapse (Robertson, 1998). Eratosthenes probably began as a fragment that rifted away from Africa in the Triassic on thinned continental crust and subsided prior to uplift in early Miocene. The collision has greatly reduced and almost stopped the convergence between Cyprus and Eratosthenes. Continued convergence is taken up in large measure by sinistral wrenching along the Latakia and Larnica Ridges east of Cyprus (Ben-Avraham et al., 1995), and dextral wrenching along the Florence Rise to the west (Woodside et al., 2000b). Transpressional and transtensional features are observed along both sides of the arc. Collision may also be responsible for breakup of the African plate between Egypt and Cyprus, with the creation of the intermediate Sinai Plate (Mascle et al., 2000).

Tectonic activity related to plate interactions is partially obstructed by superficial deformation within the sediments overlying lubricating Messinian salts. Resulting structures associated with the Mediterranean Ridge include (1) north-directed thrusts where the sediment is gliding into deeper areas (as in the southern Rhodes Basin (Woodside et al., 2000a) and elsewhere along the inner deformation front), (2) shear faults and flower structures along the outer margin of the eastern branch of the Mediterranean Ride where differential movement of sediments is observed in a northeast-southwest direction, and (3) shearing and extension within the central, most-compressed part of the Mediterranean Ridge which provides pathways for fluid escape and mud volcanism from overpressured reservoirs below. Sometimes these structures are mistaken for - although they may be a response to - deep-seated tectonics.

\section{Acknowledgments}

The ideas and data used in this paper come from too many sources to acknowledge properly. The Training Through Research Programme has been an important catalyst for recent research advances in the eastern Mediterranean; thus I thank TTR colleagues (especially Michael Ivanov) for this. The ODP drilling is in part a recognition of this. PRISMED data come from Jean Mascle. I have been funded from a number of projects for recent research, including ANAXIPROBE (NWO Project 750.195.02), MEDINAUT (NWO Project 750.199.01), MediSed (NWO Project 809.63.011), and NWO subsidies F.00.07, F199.03, and F198.16. 


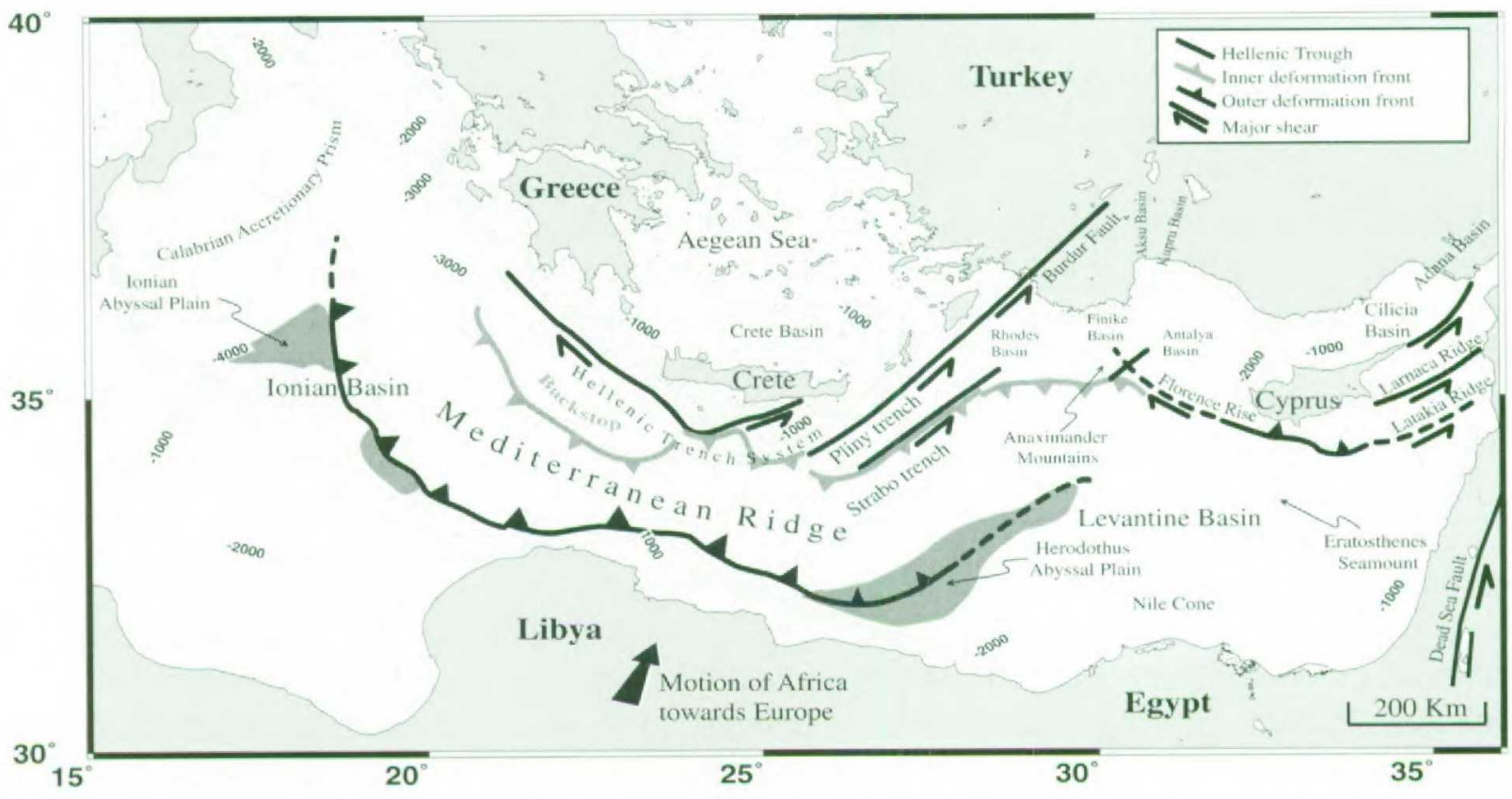

Figure 1. This is a schematic view of the eastern Mediterranean region showing places and features mentioned in the text.

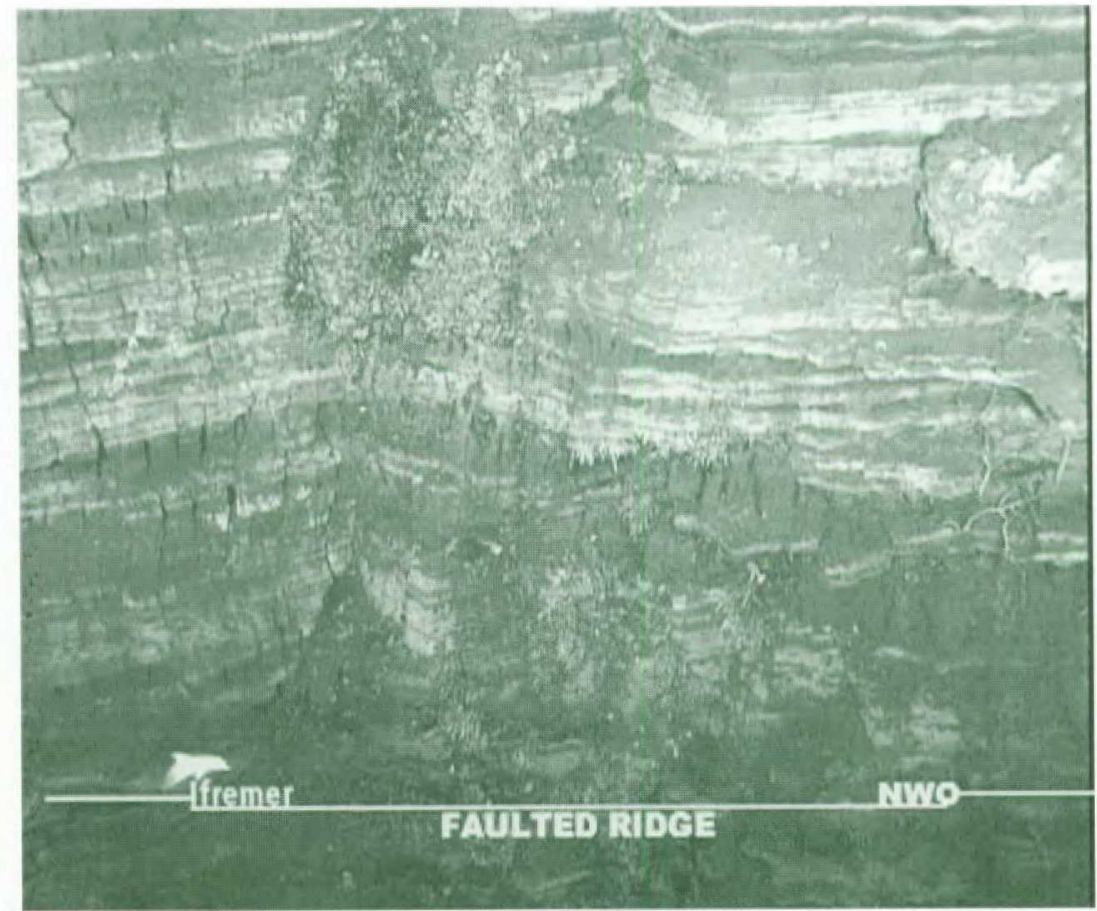

Figure 2. Fault scarp (oriented NE-SW) cutting across the Anaximander Mountains. The rocks are of Bey Dagları affinity; they are similar to those onshore in Turkey. Gas seeps through fractures along the scarp are indicated by the presence of clusters of vestimentiferan worms. This is a photograph at a depth of about $1800 \mathrm{~m}$ from the submersible Nautile during the MEDINAUT expedition in December 1998. 


\section{References}

Ben-Avraham, Z., Tibor, G., Limonov, A.F., Leybov, M.B., Ivanov, M.K., Tokarev, M.Yu., and Woodside, J.M., 1995, Structure and Tectonics of the eastern Cyprean Arc. Marine and Petroleum Geology, 12(3):263-271.

Le Pichon, X., Chamot-Rooke, N., Lallemant, S., Noomen, R., and Veis, G., 1995, Geodetic determinations of central Greece with respect to Europe: implications for eastern Mediterranean tectonics. Journal of Geophysical Research, 100:12675-12690.

Mascle, J., Benkhelil, J., Bellaiche, G., Loncke, L., Zitter, T., Woodside, J., and the Prismed II Scientific Party, 2000, Marine geological evidence for a Levantine-Sinai plate, a missing piece of the Mediterranean puzzle. Geology, in press.

McClusky, S., Balassanian, S., Barka, A., Demir, C., Ergintav, S., Georgiev, I., Gurkan, O., Hamburger, M., Hurst, K., Kahle, H., Kastens, K., Kekelidze, G., King, R., Kotzev, V., Lenk, O., Mahmoud, S., Mishin, A., Nadariya, M., Ouzounis, A., Paradissis, D., Peter, Y., Prilepin, M., Reilinger, R., Sanli, I., Seeger, H., Tealeb, A., Toksoz, M.N., and Veis, G., 2000, Global positioning system constraints on plate kinematics and dynamics in the eastern Mediterranean and Caucasus, Journal of Geophysical Research, 105:5695-5719.

McKenzie, D.P., 1972, Active tectonics of the Mediterranean region. Geophysical Journal of the Royal Astronomical Society, 30:109-185.

Robertson, A.H.F., 1998, Mesozoic-Tertiary evolution of the easternmost Mediterranean area: integration of marine and land evidence. In Robertson, A.H.F., Emeis, K.-C., Richter, C., and Camerlenghi, A. (Eds.), Proceedings of the Ocean Drilling Program, Scientific Results, 160:723782.

Sage, $L_{-}$, and Letouzey, $\mathbf{J}_{.}, 1990$, Convergence of the African and Eurasian plate in the eastern Mediterranean, in J. Letouzey (ed.) "Petroleum and Tectonics in Mobile Belts", Editions Technip, Paris, 49-68.

Woodside, J., Mascle, J., Huguen, C., and Volkonskaia, A., 2000a, The Rhodes Basin, a PostMiocene Tectonic Trough. Marine Geology, 165:1-12.

Woodside, J.M., Mascle, J., Zitter, T.A.C., Limonov, A.F., Ergün, M., Volkonskaia, A., and shipboard scientists of the PRISMED II Expedition, 2000b, The Florence Rise, the Western Bend of the Cyprus Arc, in preparation. 